\title{
Upper mantle deformation signatures of craton-orogen interaction in the Carpathian-Pannonian region from SKS anisotropy analysis
}

\author{
Laura Petrescu ${ }^{\mathrm{a}, \mathrm{b}, *}$, Graham Stuart ${ }^{\mathrm{c}}$, Gregory Houseman ${ }^{\mathrm{c}}$, Ian Bastow ${ }^{\mathrm{d}}$ \\ ${ }^{a}$ National Institute for Earth Physics, Magurele-Ilfov, Romania \\ ${ }^{b}$ Istituto Nazionale di Geofisica e Vulcanologia, Bologna, Italy \\ ${ }^{c}$ University of Leeds, Leeds, UK \\ ${ }^{d}$ Department of Earth Science and Engineering, Imperial College London, London, UK
}

\begin{abstract}
Since the Mesozoic, central and eastern European tectonics have been dominated by the closure of the Tethyan Ocean as the African and European plates collided. In the Miocene, the edge of the East European Craton and Moesian Platform were reworked in collision during the Carpathian orogeny and lithospheric extension formed the Pannonian Basin. To investigate the mantle deformation signatures associated with this complex collisional-extensional system, we carry out SKS splitting analysis at 123 broadband seismic stations in the region. We compare our measurements with estimates of lithospheric thickness and recent seismic tomography models to test for correlation with mantle heterogeneities. Reviewing splitting delay times in light of xenolith measurements of anisotropy yields estimates of anisotropic layer thickness. Fast polarisation directions are mostly NW-SE oriented across the seismically slow West Carpathians and Pannonian Basin and are independent of geological boundaries, absolute plate motion direction, or an expected palaeo-slab roll-back path. Instead, they are systematically orthogonal to maximum stress directions, implying that the indenting Adria plate, the leading deformational force in Central Europe, reset the upper-mantle mineral fabric in the past $5 \mathrm{Ma}$ beneath the Pannonian Basin, overprinting the anisotropic signature of earlier tectonic events. Towards the east, fast polarisation directions are perpendicular to steep gradients of lithospheric thickness and align along the edges of fast seismic anomalies beneath the Precambrian-aged Moesian Platform in the South Carpathians and the East European Craton, supporting the idea that craton roots exert a strong influence on the surrounding mantle flow. Within the Moesian Platform, SKS measurements become more variable with Fresnel zone arguments indicating
\end{abstract}

\footnotetext{
*Corresponding author

Email address: laura.petrescu@infp.ro (Laura Petrescu)
} 
a shallow fossil lithospheric source of anisotropy likely caused by older tectonic deformation frozen in the Precambrian. In the Southeast Carpathian corner, in the Vrancea Seismic Zone, a lithospheric fragment that sinks into the mantle is sandwiched between two slow anomalies, but smaller SKS delay times reveal weaker anisotropy occurs mainly to the NW side, consistent with asymmetric upwelling adjacent to a slab, slower mantle velocities, and recent volcanism.

Keywords:

Deformation, Seismic anisotropy, Collisional orogen, Craton, Extensional basin

\section{1. Background}

2 The most direct constraints available on active and fossil deformation in the upper mantle 3 are measurements of seismic anisotropy from core-refracted teleseismic SKS waves (Long and 4 Becker, 2010; Silver and Chan, 1988; Vauchez and Nicolas, 1991). SKS anisotropy represents 5 the composite seismic response of the mantle and lithosphere and their integrated deforma6 tional history. Large-scale coherent alignment of anisotropic minerals in the crust (Mainprice 7 and Nicolas, 1989) and mantle (e.g. Karato et al., 2008), also referred to as lattice preferred 8 orientation (LPO), is widely accepted as the dominant source of seismic anisotropy (e.g. Long 9 and Becker, 2010). Olivine, the most abundant and anisotropic mineral in the mantle can align with the maximum shear direction in a dislocation creep regime (Nicolas and Christensen, 1987 ) down to the Lehman discontinuity ( $220 \mathrm{~km}$, Meissner et al., 2002), or in the maximum 12 extension direction (Vinnik et al., 1992; Ribe, 1992), providing key insights into upper-mantle deformation and flow. The differential velocity between the lithosphere and asthenosphere may 14 create flow parallel to the plate motion (e.g. Silver, 1996). Processes like subduction and slab roll-back can introduce poloidal and toroidal flow patterns (e.g. Zandt and Humphreys, 2008; Faccenda and Capitanio, 2012; Venereau et al., 2019), and variations in lithospheric thickness can deflect asthenospheric flow (e.g. Assumpçao et al., 2002; Miller and Becker, 2012; King and Anderson, 1998). However, the reorientation of olivine in response to changing surface kinematics is not instantaneous (e.g. Skemer et al., 2012; Boneh et al., 2015). Fossil anisotropy in the lithosphere recording past deformational events can also contribute to the observed SKS signal (e.g. Silver and Chan, 1988; Bastow et al., 2007; Liddell et al., 2017). Discriminating between these different sources of anisotropy is challenging, particularly in regions of collision between tectonic units of different ages whose variably thick lithospheres may record previous tectonic histories or influence the underlying flow patterns (e.g. Deschamps et al., 2008). 
The Pannonian-Carpathian region (Figure 1) is a natural laboratory to study the interplay between past and present tectonic deformation and to investigate the variability of anisotropy sources across terranes of different ages and lithospheric thicknesses in a complex craton-orogen collision-extension system. The region comprises the geologically young tectonic units Alcapa, Tisza, and Dacia which collided with the East European Craton in the Miocene, forming the Carpathian orogenic system (Schmid et al., 2008). The collision was an indirect result of convergence of the African Plate and its Adriatic promontory towards Eurasia, which closed the Neotethys ocean and allowed tectonic escape of Alpaca, Tisza, and Dacia into the Carpathian embayment (Ustaszewski et al., 2008). Slab roll-back is interpreted to have advanced northeastward across the present-day location of the Pannonian and possibly the Transylvanian Basins (Linzer, 1996; Matenco and Radivojević, 2012) until subduction ended 9 Ma ago (Maţenco and Bertotti, 2000), choked by the hard-collision with the Precambrian units of Europe: the East European craton and the Moesian Platform (Figure 1). The margin of the East European Craton, also known as the "Trans European Suture Zone" (Pharaoh et al., 2006), is one of the most important tectonic sutures in Europe, extending from the Baltic Sea to the Black Sea, marking the boundary between Precambrian-aged tectonically stable geological units of Europe and younger accreted Phanerozoic terranes. The TESZ also corresponds to a sudden increase in lithospheric thickness ( $230 \mathrm{~km}$ : Babuška et al., 1987; Plomerová and Babuska, 2010; Geissler et al., 2010) and the edge of strong positive seismic anomalies usually associated with cratonic material (Zielhuis and Nolet, 1994; Ren et al., 2012). In Romania the TESZ is obscured beneath the Carpathian orogen and its location is disputed (e.g. Atanasiu et al., 2005; Bocin et al., 2013). Extension in the Carpathian back-arc region was coeval with collision, and formed the intra-Carpathian basins (Cloetingh et al., 2005). Post-Miocene indicators of deformation suggest that the Pannonian Basin has shortened in the past 5 Ma, most likely due to the continuous push of Adria, although recent structural measurements and present-day geodetic measurements indicate small surface strain rates (Bada et al., 2007). Beneath the Carpathian bend zone, high rates of seismicity are associated with an anomalous lithospheric block (Ren et al., 2012) that is stretching as it sinks into the mantle (Lorinczi and Houseman, 2009) and may be actively detaching from the overlying cratonic lithosphere (Gîrbacea and Frisch, 1998; Knapp et al., 2005; Petrescu et al., 2019). The Pannonian-Carpathian system is thus an excellent craton-orogen tectonic system, where we can address long-standing issues of mantle deformation in response to changing surface kinematics, to assess the complex flow field across tectonic units of variable ages and around a localised zone of intermediate-depth 
seismicity at the craton margin.

To place constraints on the flow pattern in the upper mantle and to detect possible signatures of fossil lithospheric deformation from past tectonic activity we review past measurements and present 123 new measurements of the shear wave splitting parameters of SKS waveforms from teleseismic earthquakes recorded at broadband temporary and permanent stations in Central and Eastern Europe. The new dataset significantly increases the density of anisotropy measurements in this region, enabling a better understanding of the variability of anisotropy sources and the geodynamic processes that shaped the margin of the East European Craton and the upper-mantle deformation in the circum-cratonic region. SKS splitting analysis is one of the best methods to constrain upper mantle azimuthal anisotropy (e.g. Silver and Chan, 1991; Savage, 1999). When an initially radially-polarised shear wave enters an anisotropic medium, it splits between two orthogonally polarised waves, resulting in elliptical particle motion and energy on the radial and tangential seismogram components (Figure 2). The polarisation direction of the fast shear wave, $\phi$, and the delay time, $d t$ provide information on the orientation, strength, and/or thickness of the anisotropic layer. Anisotropy in the upper mantle is generally attributable to large-scale alignment of olivine crystallographic a-axes due to shear deformation (Zhang and Karato, 1995).

We assess the origin of the observed anisotropy by comparing our measurements using the most recent and highest resolution upper mantle seismic tomography model to date (Ren et al., 2012). We also compare SKS directions with plate motion rates in different reference systems (Kreemer et al., 2014; DeMets et al., 2010; Gripp and Gordon, 2002), and measurements of principal stress orientations (Bada et al., 2007; Dombrádi et al., 2010), to infer the age of the observed anisotropy and provide insights into possible mantle flow changes indicated by postMiocene fault reactivation within the Pannonian Basin. We use SKS delay times along with previous petrological measurements of anisotropy from mantle xenoliths (Kovács et al., 2012) to compute the thickness of a theoretical anisotropic layer beneath the region. Our measurements form the densest and most up-to-date dataset of anisotropy in Central and Eastern Europe, providing the best available indicators of the recent deformation field of the upper mantle beneath the Pannonian-Carpathian system. 


\section{Method}

To determine the fast shear wave polarisation direction $(\phi)$ and the splitting delay time $(d t)$, we used the method of Silver and Chan (1991). Horizontal component seismograms were rotated in the great circle arc coordinates and time-shifted to minimise the second eigenvalue of the covariance matrix of particle motion within a time window around the SKS wave arrival. This results in the reduction of shear wave energy on the tangential component and linearisation of the particle motion (Figure 2). We used the automated window selection technique of Teanby et al. (2004) to estimate $\phi$ and $d t$ via cluster analysis of the results from 100 different windows (Figure 2). Our errors are based on the method of Silver and Chan (1991) under the assumption of a Gaussian noise distribution which can result in values that are underestimated by $\sim 3^{\circ}$ and $0.01 \mathrm{~s}$ for $\phi$ and $d t$, respectively (Walsh et al., 2013). An un-split shear wave, where a high signal-to-noise ratio SKS phase is visible on the radial component but lacking on the transverse is referred to as a null measurement (Figure 2b). In this case, the resulting particle motion is already linear and error surfaces lack a clearly constrained region for the best $\phi-d t$ pair. A null measurement may be generated if the medium is not azimuthally anisotropic or if there are multiple layers of differing anisotropy whose splitting effect cancels out (e.g. Barruol and Hoffmann, 1999). If the SKS wave has an initial polarisation that is parallel or orthogonal to the true anisotropy direction, it would not be split and null measurements would be expected along the "null lines" in Figure 3. Furthermore, we systematically measured the difference between earthquake back-azimuth and the incoming polarisation direction of SKS energy and removed measurements where this difference was $\geq 20^{\circ}$ to avoid contamination of our upper mantle anisotropic dataset with either D" anisotropy (Restivo and Helffrich, 2006) or errors due to station misalignments (see Supplementary Material).

To obtain an estimate of anisotropy that is representative of a given station we stacked the misfit surfaces associated with individual splitting solutions excluding null measurements (Figures 2,3), weighted by their signal-to-noise ratio (Restivo and Helffrich, 1999). This stacking procedure assumes a single, horizontal, homogenous layer of anisotropy beneath the region. Backazimuthal variation of SKS splitting solutions may be evidence of multiple layers of anisotropy. However, most earthquakes with acceptable SKS solutions were found in the $60-80^{\circ}$ and 250 $300^{\circ}$ back-azimuth ranges (Figure 3), multiple anisotropic layers cannot be resolved. No $90^{\circ}$ periodicity or large peak -to-peak $\phi$ variations characteristic of a two-layer model (Silver and Savage, 1994), are evident in the data. Dipping principal axes of anisotropy can also induce 
variations in $\phi$ with back-azimuth, although not as sharp as the changes caused by multiple layers (e.g. Liddell et al., 2017). Our data are not suggestive of such patterns (Figure 3), so we interpret the anisotropic signal as if it is a single layer with horizontal fast and slow polarisation axes.

SKS delay times are dependent on the SKS path-length in the anisotropic layer and the strength of the anisotropic fabric (Silver and Chan, 1991; McNamara et al., 1994). If the average shear wave velocity and anisotropy strength can be estimated from seismic and mantle xenolith studies, respectively, and assuming that SKS phases travel through a single horizontal layer of anisotropy, the thickness of this layer may be inferred, allowing for a more direct comparison with estimates of lithospheric thickness, for example. For a shear wave with a vertical ray path traveling through a layer of anisotropic mantle material with constant isotropic shear velocity, $\beta_{0}$, the equivalent anisotropic layer thickness is $L=d t \beta_{0} / k$, where $d t$ is the SKS splitting delay time, and $k$ is the percentage anisotropy, or the fractional difference in velocity between the fast and slow polarisations (Silver and Chan, 1988). While an upper limit of the percentage of anisotropy in the upper $200 \mathrm{~km}$ is sometimes quoted as 4\% (e.g. Savage, 1999; Gilligan et al., 2016), electron-diffraction backscatter studies of peridotites, the dominant upper-mantle rock, provide S-wave anisotropy estimates of up to 10\% (Worthington et al., 2013). Mantle xenoliths from the Pannonian Basin show values between 5.4\% and 7.3\% anisotropy (Kovács et al., 2012). We thus consider results for average $k=6.35 \% \pm 0.95$. For the shear wave velocity $\beta_{0}$, we extract absolute values from a recent regional S-wave adjoint tomography model of Europe (Zhu et al., 2015) between $40 \mathrm{~km}$ and $300 \mathrm{~km}$, the depth range where we expect the main SKS anisotropy signal to reside, and use the mean $\beta_{0}$ and estimated delay times from SKS analysis at each station location (excluding nulls) to calculate the anisotropic layer thickness, $L$. By propagating the uncertainty in the $L=d t \beta_{0} / k$ equation, we obtain $\delta L=L \sqrt{\left(\frac{\delta d t}{d t}\right)^{2}+\left(\frac{\delta \beta_{0}}{\beta_{0}}\right)^{2}+\left(\frac{\delta k}{k}\right)^{2}}$. If we consider an average $\beta_{0}=4.5 \pm 0.3 \mathrm{~km} / \mathrm{s}$ (calculated from Zhu et al., 2015), $k=6.35 \pm 0.95$ (based on the range provided by Kovács et al., 2012), $d t=1.3 \pm 0.3 \mathrm{~s}$ (this study), we obtain $\delta L \approx 25 \mathrm{~km}$. In the calculation of $L$, we only vary shear wave velocity and delay time at each station location, while keeping $k$ fixed. For a map of layer thickness standard deviation map, see the Supplementary Material. 


\section{Data}

Our SKS waveforms come from 123 temporary and permanent broadband seismic stations located across Hungary, Serbia, Romania, and Moldova (Figure 1), including 54 temporary stations from the 2009-2011 South Carpathian Project (SCP: Ren et al., 2012), 68 permanent stations from the Romanian National Seismic Network (RO: Popa et al., 2015), and 4 permanent stations from the Moldova Digital Seismic Network (MD). SKS analyses for the 2005-2007 Carpathian Basin Project (CBP: Dando et al., 2011) were undertaken by both Qorbani et al. (2016) and Kovács et al. (2012).

We selected earthquakes that occurred between 2006 and 2018, with magnitudes Mw>6 and epicentral distances in the range $88^{\circ}-140^{\circ}$ with respect to the coordinates of the centre of our network (inset in Figure 1), to isolate SKS arrivals, and identified usable phases in the $85^{\circ}-122^{\circ}$ epicentral distance range at each station (see Supplementary Material). Prior to analysis, data were filtered with a zero-phase Butterworth bandpass filter with corner frequencies 0.04-0.3 Hz. Good splitting results are selected if the particle motion is successfully linearised, the corrected fast and slow waveforms are matched, and the uncertainties in $\phi$ and $d t$ are less than $20^{\circ}$ and $0.5 s$, respectively. Seismograms from 932 earthquakes yielded up to 33 high-quality non-null SKS splitting parameters, per station (see Supplementary Material). Good null results are selected if a high signal-to-noise ratio (SNR>4, Liu and Gao, 2013) SKS waveform is visible on the radial component only and energy on the transverse component is lacking from visual inspections (Figure 2), yielding high-quality null measurements of average $\mathrm{SNR}=13$. We do not use a delay time cut-off to consider a measurement null.

\section{Results}

Figures 4 and 5 show SKS results from this study as well as previously published measurements across Central and Eastern Europe (Dricker et al., 1999; Vinnik et al., 1994; Wylegalla et al., 1999; Kummerow et al., 2006; Plenefisch et al., 2001; Wiejacz, 2001; Ivan et al., 2008; Vecsey et al., 2008; Plomerová et al., 2012; Salimbeni et al., 2013; Qorbani et al., 2015, 2016; Song et al., 2019). Average $d t$ values vary between $0.4 \mathrm{~s}$ and $2.1 \mathrm{~s}$ and $\phi$ is spatially variable, but the prevalent direction is NW-SE. Permanent Romania (RO) and Moldova (MD) stations which have operated for $>10$ yrs yield splitting uncertainties of $\sim 0.2 \mathrm{~s}$ and $\sim 1.2^{\circ}$ for $d t$ and $\phi$, respectively (see Supplementary Material). 


\subsection{Relationship between anisotropy orientation and surface tectonic structures}

The prevailing pattern of anisotropy in Central and Eastern Europe is approximately NW-SE, consistent with previous studies (e.g. Ivan et al., 2002; Qorbani et al., 2016), and obliquely cross-cutting the major ENE trending geological boundaries in the Pannonian Basin (Figure 4). Fast polarisation directions gradually rotate in the Transylvanian Basin and across the East Carpathians (Figure 4), paralleling the orogen and the craton margin (Figure 1). SKS directions are typically near-parallel to the major fault systems in the East Carpathians and oblique to them in the South Carpathians (Figure 4), mostly mimicking the sinuous path of the orogen, following the edge of the thick-lithosphere Precambrian units (Figure 4). $\phi$ changes at the South-East Carpathian corner from NW-SE to NE-SW, consistent with previous SKS splitting studies of the Carpathians (Ivan et al., 2008; Stanciu et al., 2013).

\subsection{Variability of anisotropy strength}

Figure 5 shows the SKS delay times for all available measurements. We observe a general increase in $d t$ from $<1 \mathrm{~s}$ in central Pannonian Basin, to $>1.4 \mathrm{~s}$ in northeast Pannonian Basin, and to $>1.8 \mathrm{~s}$ in northeast Carpathians. In the South Carpathians, $d t=0.6-1.6 \mathrm{~s}$, decreasing in the bend zone and southeast Carpathians (Figure 5). Across the Carpathian orogen, random variation dominates a background of $d t \approx 1 \mathrm{~s}$ (Figure 5). Delay times beneath the central Pannonian Basin are consistent with a thin equivalent anisotropic layer $(\sim 50 \mathrm{~km}$, Figure 5$)$ increasing to $\sim 100 \mathrm{~km}$ beneath northeast Pannonian Basin and the Carpathians, portions of the East European Craton and the Moesian Platform (Figure 5). The apparent thickness decreases to $\sim 50 \mathrm{~km}$ beneath the Transylvanian Basin and to $<30 \mathrm{~km}$ beneath the Carpathian bend zone, where null and near-null SKS splitting values are estimated. In contrast, beneath the South-Eastern Alps, large delay times (Kummerow et al., 2006) are consistent with a thick anisotropic layer or stronger anisotropy.

\subsection{Possible complex anisotropy regions and deviations from 1-layer assumptions}

Across our study area, we interpreted our measurements as if we had a single, horizontal, homogeneous layer of anisotropy. A more complex interpretation is not justified in the light of our limited back-azimuthal earthquake coverage, which precludes the possibility that we can resolve dipping or multi-layer anisotropic fabrics. However, variations in $\phi$ at some stations suggest more complex patterns do exist in certain regions, so we acknowledge the potential 
for dipping and/or multi-layer anisotropy beneath our study area. For example, stations in central Pannonian Basin exhibit both WNW-ESE and NW-SE $\phi$ measurements (Figure 1). In the South Carpathians, both N-S and E-W directions are present. In the forearc of the SE Carpathian corner, where the Vrancea slab is located, several stations exhibit at least two main directions (N-S and NW-SE), perhaps testifying the complex flow patterns in that region. Resolving the causes of these splitting parameter variations is, unfortunately, not possible with our dataset.

\section{Discussion}

\subsection{Possible source-depth and origins of seismic anisotropy}

A long-standing ambiguity in SKS splitting data concerns the depth extent of the anisotropy and whether it represents deformation within the lithosphere or shearing of the asthenosphere (e.g. Silver, 1996; Long and Silver, 2009). Establishing the source depth of anisotropy can be aided by comparisons with estimates of lithospheric thickness and models of seismic wavespeed in the upper mantle. The most recent $\mathrm{P}$-wave seismic tomography model of the CarpathianPannonian system (Ren et al., 2012) shows large-scale negative $V p$ anomalies at lithospheric and asthenospheric depths beneath most of the Pannonian Basin, Transylvanian Basin, West and East Carpathians (Figure 6). These low velocity mantle domains are all dominated by SKS anisotropy orientations following a NW-SE mega-trend (Figures 6). The lithosphere beneath the Pannonian Basin is known to have experienced substantial lithospheric thinning (Huismans et al., 2001; Horváth et al., 2006) in the late Miocene ( 10 Ma), with an estimated Lithosphere-Asthenosphere boundary (LAB) depth of $\sim 60 \mathrm{~km}$, increasing to $\sim 80 \mathrm{~km}$ beneath the Transylvanian Basin (Figures 4,5, after Kovács et al., 2012). Structure below this depth is thus within the asthenospheric realm and our SKS splitting may be indicative of asthenospheric flow, consistent with the interpretation of Qorbani et al. (2016). While the equivalent anisotropy layer thickness is similar to lithospheric thicknesses in the SW Pannonian, in the NE it reaches values of $>100 \mathrm{~km}$, exceeding LAB depths there (Figure 5), suggesting an asthenospheric contribution to the signal. The crustal contribution to an SKS delay time is generally thought to be less significant (0.04-0.2 s, Barruol and Mainprice, 1993), considerably lower than our values. Therefore, across our study area, there is a clear mantle contribution to the SKS splitting observations.

When SKS directions parallel absolute plate motion, the anisotropy is interpreted to result 
from the differential motion between the asthenosphere and the bottom of the lithosphere (e.g. Silver, 1996). We therefore compare our SKS measurements with estimates of absolute plate motion direction (APM) in the hotspot (Gripp and Gordon, 2002) and no-net rotation frames (Kreemer et al., 2014; DeMets et al., 2010) (Figure 4). Fast axes directions differ by $\sim 10^{\circ}$ in the Eastern Alps, to $\sim 35^{\circ}$ in western and central Pannonian Basin, to $\sim 50^{\circ}$ and $\sim 70^{\circ}$ in the western Pannonian Basin, and Carpathian orogenic system, respectively. The lack of systematic correlation implies basal drag is probably not responsible for the observations and so we ask whether recent tectonic deformation and mantle heterogeneities play a more important role in controlling the upper mantle strain field than plate-motion. APM in Central and Eastern Europe varies between $22 \mathrm{~mm} / \mathrm{yr}$ and $30 \mathrm{~mm} / \mathrm{yr}$ in the hotspot and no-net rotation frames, respectively, which may be insufficient to induce spatially coherent basal drag fabrics in the underlying mantle (Debayle and Ricard, 2013; Martin-Short et al., 2015). Anisotropic fast axis directions generally align with the Alps, and the South and East Carpathians. Therefore, the anisotropic signature may be related, at least partly, to deformation of the mantle lithosphere associated with the Miocene age formation of the extensional basin and convergence in the Carpathians.

\subsection{Signatures of past and present tectonic deformation}

The response of upper mantle LPO to changing surface deformation can have a significant time-lag, depending on strain rates and pre-existing fabrics (e.g. Skemer et al., 2012), with duration estimates that vary from 6.5 Myr (Moore et al., 2002) to $45 \mathrm{Myr}$ (Little et al., 2002). The state of recent stress and ongoing deformation in Central Europe (Bada et al., 2007) has been attributed to the counter-clockwise rotation and N-NE drift of the Adriatic microplate ("Adria push", Bada et al., 2007; Caporali et al., 2009) since 4-5 Ma (Bada et al., 2007). Figure 4 illustrates our average SKS results together with the maximum horizontal stress directions estimated from crustal earthquake fault plane solutions and in-situ measurements from the World Stress Map after Bada et al. (2007). Dominant fast polarisation directions are mostly perpendicular to the horizontal stress isolines throughout the Eastern Alps and the central and eastern Pannonian Basin (Figure 4). Despite the estimated stress directions being inferred from indicators within the crust, their systematic orthogonality with shear wave anisotropy may be related to a past deformation of crust and mantle lithosphere that affected both similarly. In such a deformation field the fast polarisation direction is expected to be determined by a fabric lineation orthogonal to the shortening direction (e.g. Meissner et al., 2002; McNamara et al., 
1994; Bokelmann et al., 2013).

Extension in the Pannonian Basin may have originated from gravitational collapse due to the over-thickened surrounding orogens and/or subduction roll-back (Tari et al., 1992; Ustaszewski et al., 2008). Trench retreat advanced north-eastwards in the Carpathian embayment along a $\sim 500 \mathrm{~km}$ path towards the East European Craton (Handy et al., 2015), until 11 Ma ago (Linzer, 1996; Fodor et al., 1999). Subduction roll-back may have been coeval with back-arc extension in the Pannonian Basin (Cloetingh et al., 2005). The large-scale mantle deformation of this system might be expected to imprint an anisotropic fabric in the upper mantle, causing possible trench-normal anisotropy (e.g. Lucente et al., 2006; Druken et al., 2011). However, the alignment of fast polarisation directions parallel to the East Carpathians and the TESZ (Figure 4) does not support the idea that the present anisotropic signature of the region can be explained by the north-eastward palaeo-slab roll-back across the region now occupied by the Pannonian and the Transylvanian Basins (Figure 4), implying that the present state of deformation may have been reset since crustal extension ceased at $\sim 11$ Ma. While Kovács et al. (2012) suggested that Miocene large-scale magmatism could erase, at least partly, previous LPO anisotropy, the scale of recent deformation is incomparably smaller than the extensional phase coeval with the Carpathian orogenic activity that ended $\sim 11 \mathrm{Ma}$ ago. The last significant deformation known to have affected the crust in this region and to have caused the anisotropy fabrics in the Pannonian Basin under the assumption of a coherent lithospheric deformation thus remains the compression exerted by the indentation of Adria in the past $\sim 5 \mathrm{Ma}$ (Bada et al., 2007). Arguing against this mechanism is the observation that NW-SE $\phi$ values parallel the TESZ, well within the East European Craton (e.g. Dricker et al., 1999; Wiejacz, 2001). A stress field unrelated to Africa-Adria convergence perhaps therefore influences a broad swath of south-central Europe or Adria indentation has a far reaching effect that extends into the craton.

\subsection{Asthenospheric upwelling in the Transylvanian intra-arc basin}

Beneath the Transylvanian Basin and the volcanic part of the East Carpathians, a large-scale, low $V p$ anomaly exists at lithospheric and asthenospheric depths (Figure 6). Upwelling of mantle material may orient olivine crystal fabric vertically, rendering the mantle virtually isotropic to the almost vertically incident SKS waves. This would explain the null/low $d t$ observations in Figure 5, akin to other areas of putative vertical asthenospheric motion (e.g. Xue and Allen, 2005; De Plaen et al., 2014). Beneath the East Carpathians, upwelling of low-Vp asthenosphere has been proposed and supported with independent seismic measurements (e.g. Ren 
et al., 2012; Borleanu et al., 2017). The upwelling hypothesis (Göğüs et al., 2016; Maţenco, 2017; Şengül Uluocak et al., 2019) is also supported by the occurrence of post-collisional volcanism (Seghedi et al., 2011), and the observed high heat flux values (up to $126 \mathrm{~mW} / \mathrm{m}^{2}$ locally, Demetrescu and Veliciu, 1991). A reduction in $d t$ can alternatively be explained by the presence of melt and/or water, which can drastically alter mantle velocities and LPO behaviour (Karato and Jung, 1998; Katayama et al., 2004), by promoting the transition from dislocation creep to diffusion creep, which prevents the formation of a preferred mineral orientation (e.g. Kendall, 1994).

\subsection{Craton margin-parallel flow and the influence of regional-scale heterogeneities on mantle} deformation

Fast polarisation directions rotate progressively clockwise from west to east (Figure 6), aligning with the seismically fast and thick lithosphere of the East European Craton, whose margin, the TESZ, is overridden by the Carpathian nappes. In tomography cross-sections, the East Carpathians are partially underlain by a seismically fast anomaly with a vertically concave boundary (Figure 6) that corresponds to an increase in LAB (Figure 5) and probably marks the continuation of the TESZ into the mantle. SKS fast axes orient parallel to the edge of this anomaly, suggesting elongation of mineral fabric parallel to the craton margin (Figure 6, profile C) and display especially large delay times in the NE Pannonian (1.5-2 s, Figure 5). Trenchparallel flow as evidenced by SKS splitting was also reported in several classic subduction systems worldwide (e.g. Long and Silver, 2008; Russo and Silver, 1994) and cases of cratonparallel alignment of flow have also been observed in other parts of the world (Assumpção et al., 2006; Eaton et al., 2004; Miller and Becker, 2012; Venereau et al., 2019). SKS measurements on the seismically-fast craton-side also show edge-parallel directions, probably suggesting preexisting frozen deformation within the craton or deformation related to the collision.

The Moesian Platform, also a thick-lithosphere Precambrian-aged tectonic unit separate but abutting the East European Craton was sutured onto the craton in the Jurassic (Schmid et al., 2008). An extensive fast seismic anomaly underlies the Moesian Platform and part of the South and South-East Carpathians, which override it obliquely, and extends towards the mantle transition zone (Figure 6). SKS fast directions switch from the NW-SE Pannonian megatrend to a NE-SW direction, closely following the edge of the seismically fast lithospheric block, but

further west they come into alignment again with the strike of the South Carpathian chain. Most continental collision zones exhibit anisotropy that is parallel to the structural grain of the orogen 
(e.g. Barruol et al., 2011; Salimbeni et al., 2018) and have often been interpreted as showing the direction of asthenospheric flow in response to collision (e.g. Meissner et al., 2002) or a combined effect of asthenospheric origin and vertically coherent deformation within the lithosphere ( Wang et al., 2008; Chang et al., 2015; Kuo et al., 2018). The South Carpathian orogen has a complex evolutionary history including Eocene orogen-parallel extension and metamorphic core complex formation followed by Oligocene dextral strike-slip faulting, then Miocene thrusting onto the Moesian platform (Iancu et al., 2005). The alignment of SKS directions with the edge of the platform is generally consistent with this multi-phase orogenic history. Within the undeformed Moesian foreland, SKS directions become spatially incoherent at stations $\sim 50 \mathrm{~km}$ apart (Figure 4). At $\sim 100 \mathrm{~km}$ depth, Fresnel zones of SKS waves from these nearby stations start to overlap (Alsina and Snieder, 1995), suggesting that the anisotropic fabric is located above this depth. Since the LAB depth is estimated $180-200 \mathrm{~km}$ in this area (Figure 5), the anisotropy is likely a signature of fossil deformation within the Precambrian lithosphere.

\subsection{Vrancea slab anisotropic signature and geodynamic implications}

The northeastern tip of the seismically fast Moesian lithosphere extends beneath the Carpathian bend zone and is actively detaching from the overlying lithosphere, causing large magnitude intermediate-depth seismicity (Ismail-Zadeh et al., 2012). Multiple seismic tomography models detect a vertical zone of high-speed material here (e.g. Martin et al., 2006; Ren et al., 2012; Baron and Morelli, 2017), associated with either a downward sinking slab in the final stage of break-off (Wortel and Spakman, 2000; Sperner et al., 2001), an actively delaminating mantle lithospheric fragment (Gîrbacea and Frisch, 1998; Fillerup et al., 2010), or drip-like gravitational instability of the mantle-lithosphere (Lorinczi and Houseman, 2009). Our measurements of NESW $\phi$ directions corroborate previous studies (Ivan et al., 2008; Popa et al., 2008). While some cross-sections through regional tomography models appear to show the seismically fast Vrancea slab connected to the NE with a similarly high-speed region (Wortel and Spakman, 2000; Bijwaard and Spakman, 2000), indicative of a delamination model, the finite-frequency P-wave tomography of Ren et al. (2012) shows a shallow $(\sim 200 \mathrm{~km})$ tongue of fast material connected to the Moesian Platform to the SW, forming an axisymmetric anomaly at depths below the active seismicity. Above $\sim 200 \mathrm{~km}$ the fast anomaly is bounded to east and west by relatively slow material (Ren et al., 2012), consistent with the drip model, in which hot asthenospheric upwelling occurs adjacent to the dense sinking material. However, the decreased $d t$ observations on the intra-arc side (Figure 4) suggests that mantle upwelling or reduced deformation occurs 
only to the NW of the Vrancea anomaly, consistent with the type of asymmetric downwelling presented in the 3D numerical model of Lorinczi and Houseman (2009). East and SE of the Vrancea Zone, $\phi$ orients N-S and $d t>1.6 \mathrm{~s}$, observations that are unlikely to be associated with upwelling, but suggest a distinct fossil anisotropic signature on the foreland side of the slab.

\section{Conclusions}

To investigate the mantle deformation of the Carpathian-Pannonian region in Central and Eastern Europe, we supplemented the existing dataset of seismic anisotropy measurements with 123 SKS splitting observations from the western Pannonian Basin, the Carpathian orogen, the East European Craton, and the Moesian Platform (Figure 4). We interpret seismic anisotropy in light of seismic tomography models, absolute plate motion, and present-day stress estimates.

SKS fast axes follow a general NW-SE orientation across the Bohemian Massif, West Carpathians and the Pannonian Basin, with no apparent correlation to surface geology, nor absolute plate motion, suggesting that large-scale continental motion relative to deeper mantle does not induce coherent deformation in the asthenosphere. We find a systematic orthogonality to maximum horizontal stress in the Pannonian Basin, which has been experiencing tectonic inversion due to the indentation of Adria since 5 Ma. We hypothesise that the mantle trapped between Adria and the East European Craton may be extending perpendicular to the indentation of Adria, the leading deformation force in Central Europe. The upper-mantle mineral fabric possibly associated with past subductions, the closure of the Neotethys, paleo-slab roll-back and extension of the Pannonian Basin appear to have been over-written.

In the NE Pannonian Basin towards the craton margin, $d t$ values approach $1.9 \mathrm{~s}$, consistent with a thicker anisotropic layer and/or stronger fabric. Fast axes progressively align with the margin of the thick-lithosphere East European Craton, indicating mantle flow parallel to the craton edge. In the Transylvanian Basin null and near-null observations are consistent with an asthenospheric upwelling hypothesis that also explains recent volcanism and high heat flux measurements.

A large fast seismic anomaly beneath the South-East Carpathians in the Vrancea Area and the Moesian Platform, extending towards the mantle transition zone causes a regional-scale disturbance to $\phi$ observations, emphasising a strong correlation between seismic heterogeneities 
and the state of upper-mantle deformation. SKS results suggest that mantle upwelling or reduced deformation indicated by a reduced anisotropic signature occurs mainly to the NW of the Vrancea anomaly implying asymmetric downwelling. The relatively rigid Moesian lithospheric block may be sufficiently thick to deflect mantle flow around its edges. Within the undeformed Moesian foreland, neighbouring stations show more variable SKS directions, suggestive of a shallow fossil lithospheric source for the detected anisotropy.

\section{Acknowledgments}

LP is supported by the Romanian Ministry of Research and Innovation Research Grant NUCELU MULTIRISC PN19080102. GS acknowledges support from a Bristol University Colston visiting professorship for part of his contribution to this paper. The South Carpathian Project (SCP) was supported by NERC standard grant NE/G005931/1; the Carpathian Basin Project (CBP) by grant NE/C004574/1. The NERC Geophysical Equipment Facility, SEIS-UK, provided the seismological equipment used for these temporary networks. The fieldwork for the SCP project was a collaborative project between the University of Leeds, UK, National Institute of Earth Physics (NIEP), Bucharest, Romania, Etövös Loránd Geophysical Institute (ELGI), Budapest, Hungary, and the Seismological Survey of Serbia (SSS), Belgrade, Serbia. The South Carpathian Project Working Group includes: G. Houseman, G. Stuart, Y. Ren, B. Dando, P. Lorinczi, O. Gogus (University of Leeds, UK); C. Ionescu, M. Radulian, V. Răileanu, D. Tătaru, B. Zaharia, F. Borleanu, C. Neagoe, G. Găinariu, D. Rau (NIEP); E. Hegedüs, A. Kovács, I. Török, I. László, R. Csabafi (ELGI); S. Radovanovic, V. Kovacevic, D. Valcic, S. Petrovic-Cacic, G. Krunic (SSS); A. Brisbourne, D. Hawthorn, V. Lane (SEIS-UK, Leicester University, UK). We acknowledge Prof. Marian Ivan for detailed comments on the manuscript. Data from permanent stations used in this study were obtained from the Romanian National Seismic Network provided by NIEP, and from GFZ, ORFEUS and IRIS seismological data archives. Most figures were made using GMT software (Wessel and Smith, 1998). 


\section{References}

Ádám, A., and V. Wesztergom (2001), An attempt to map the depth of the electrical asthenosphere by deep magnetotelluric measurements in the Pannonian Basin (Hungary), Acta Geol. Hung., 44(2-3), 167-192.

Alsina, D., and R. Snieder (1995), Small-scale sublithospheric mantle deformation: constraints from SKS splitting opbservations., Geophys. J. Int., 123, 431-448, doi:10.1111/j.1365246X.1995.tb06864.x.

Assumpçao, M., D. James, and A. Snoke (2002), Crustal thicknesses in SE Brazilian Shield by receiver function analysis: Implications for isostatic compensation, J. Geophys. Res., 107(B1), 1-14, doi:10.1029/2001JB000422.

Assumpção, M., M. Heintz, A. Vauchez, and M. Silva (2006), Upper mantle anisotropy in SE and central Brazil from SKS splitting: Evidence of asthenospheric flow around a cratonic keel, Earth Planet. Sci. Lett., 250(1-2), 224-240, doi:10.1016/j.epsl.2006.07.038.

Atanasiu, L., M. Mandea, D. Zugrăvescu, and M. Roharik (2005), Trans-European Suture Zone over the Romanian territory in the light of new satellite data, Rev. Roum. Géophysique, 49, $49-61$.

Babuška, V., J. Plomerová, and J. Š́lenỳ (1987), Structural model of the subcrustal lithosphere in central Europe, Composition, Structure and Dynamics of the Lithosphere-Asthenosphere System, 16, 239-251.

Bada, G., F. Horváth, P. Dövényi, P. Szafián, G. Windhoffer, and S. Cloetingh (2007), Presentday stress field and tectonic inversion in the Pannonian basin, Global and Planetary Change, 58(1-4), 165-180, doi:10.1016/j.gloplacha.2007.01.007.

Baron, J., and A. Morelli (2017), Full-waveform seismic tomography of the Vrancea, Romania, subduction region, Phys. Earth Planet. Int., 273, 36-49, doi:10.1016/j.pepi.2017.10.009.

Barruol, G., and R. Hoffmann (1999), Upper mantle anisotropy beneath the Geoscope stations, J. Geophys. Res., 104(B5), 10,757-10, doi:10.1029/1999JB900033.

Barruol, G., and D. Mainprice (1993), A quantitative evaluation of the contribution of crustal rocks to the shear-wave splitting of teleseismic SKS waves., Phys. Earth Planet. Int., 78, 281-300, doi:10.1016/0031-9201(93)90161-2. 
Barruol, G., M. Bonnin, H. Pedersen, G. H. Bokelmann, and C. Tiberi (2011), Belt-parallel mantle flow beneath a halted continental collision: The Western Alps, Earth Planet. Sci. Lett., 302(3-4), 429-438, doi:10.1016/j.epsl.2010.12.040.

Bastow, I., T. Owens, G. Helffrich, and J. Knapp (2007), Spatial and temporal constraints on sources of seismic anisotropy: Evidence from the Scottish highlands, Geophys. Res. Lett., 34(5), L05305, doi:10.1029/2006GL028911.

Bielik, M., Z. Alasonati-Tašárová, H. Zeyen, J. Dérerová, J. Afonso, and K. Csicsay (2010), Improved geophysical image of the Carpathian-Pannonian basin region, Acta Geodaet. et Geophys. Hung., 45(3), 284-298, doi:10.1556/AGeod.45.2010.3.3.

Bijwaard, H., and W. Spakman (2000), Non-linear global P-wave tomography by iterated linearized inversion, Geophys. J. Int., 141(1), 71-82, doi:10.1046/j.1365-246X.2000.00053.x.

Bocin, A., R. Stephenson, L. Matenco, and V. Mocanu (2013), Gravity and magnetic modelling in the Vrancea Zone, south-eastern Carpathians: redefinition of the edge of the East European Craton beneath the south-eastern Carpathians, Geodyn., 71, 52-64, doi: 10.1016/j.jog.2013.08.003.

Bokelmann, G., E. Qorbani, and I. Bianchi (2013), Seismic anisotropy and large-scale deformation of the Eastern Alps, Earth Planet. Sci. Lett., 383, 1-6, doi:10.1016/j.epsl.2013.09.019.

Boneh, Y., L. F. Morales, E. Kaminski, and P. Skemer (2015), Modeling olivine CPO evolution with complex deformation histories: Implications for the interpretation of seismic anisotropy in the mantle, Geochem. Geophys. Geosyst., 16(10), 3436-3455, doi:10. 1002/2015GC005964.

Borleanu, F., L. De Siena, C. Thomas, M. Popa, and M. Radulian (2017), Seismic scattering and absorption mapping from intermediate-depth earthquakes reveals complex tectonic interactions acting in the Vrancea region and surroundings (Romania), Tectonophysics, 706, 129-142, doi:10.1016/j.tecto.2017.04.013.

Caporali, A., C. Aichhorn, M. Barlik, M. Becker, I. Fejes, L. Gerhatova, D. Ghitau, G. Grenerczy, J. Hefty, S. Krauss, et al. (2009), Surface kinematics in the Alpine-Carpathian-Dinaric and Balkan region inferred from a new multi-network GPS combination solution, Tectonophysics, 474(1-2), 295-321, doi:10.1016/j.tecto.2009.04.035.

Chang, L., L. M. Flesch, C.-Y. Wang, and Z. Ding (2015), Vertical coherence of deformation in lithosphere in the eastern Himalayan syntaxis using GPS, Quaternary fault 
slip rates, and shear wave splitting data, Geophys. Res. Lett., 42(14), 5813-5819, doi: 10.1002/2015GL064568.

Cloetingh, S., L. Maţenco, G. Bada, C. Dinu, and V. Mocanu (2005), The evolution of the Carpathians-Pannonian system: interaction between neotectonics, deep structure, polyphase orogeny and sedimentary basins in a source to sink natural laboratory, Tectonophysics, 410(14), 1-14, doi:10.1016/j.tecto.2005.08.014.

Dando, B., G. Stuart, G. Houseman, E. Hegedüs, E. Brückl, and S. Radovanović (2011), Teleseismic tomography of the mantle in the Carpathian-Pannonian region of central Europe, Geophys. J. Int., 186(1), 11-31, doi:10.1111/j.1365-246X.2011.04998.x.

De Plaen, R., I. Bastow, E. Chambers, D. Keir, R. Gallacher, and J. Keane (2014), The development of magmatism along the Cameroon Volcanic Line: evidence from seismicity and seismic anisotropy, J. Geophys. Res., 119(5), 4233-4252, doi:10.1002/2013JB010583.

Debayle, E., and Y. Ricard (2013), Seismic observations of large-scale deformation at the bottom of fast-moving plates, Earth Planet. Sci. Lett., 376, 165-177, doi:10.1016/j.epsl.2013.06.025.

Demetrescu, C., and S. Veliciu (1991), Heat flow and lithosphere structure in Romania, in Terrestrial Heat Flow and the Lithosphere Structure, pp. 187-205, Springer.

DeMets, C., R. G. Gordon, and D. F. Argus (2010), Geologically current plate motions, Geophys. J. Int., 181(1), 1-80, doi:10.1111/j.1365-246X.2009.04491.x.

Deschamps, F., S. Lebedev, T. Meier, and J. Trampert (2008), Stratified seismic anisotropy reveals past and present deformation beneath the East-central United States, Earth Planet. Sci. Lett., 274 (3-4), 489-498, doi:10.1016/j.epsl.2008.07.058.

Dombrádi, E., D. Sokoutis, G. Bada, S. Cloetingh, and F. Horváth (2010), Modelling recent deformation of the Pannonian lithosphere: lithospheric folding and tectonic topography, Tectonophysics, 484(1-4), 103-118, doi:10.1016/j.tecto.2009.09.014.

Dricker, I., L. Vinnik, S. Roecker, and L. Makeyeva (1999), Upper-mantle flow in eastern Europe, Geophys. Res. Lett., 26(9), 1219-1222, doi:10.1029/1999GL900204.

Druken, K., M. Long, and C. Kincaid (2011), Patterns in seismic anisotropy driven by rollback subduction beneath the High Lava Plains, Geophys. Res. Lett., 38(13), doi: 10.1029/2011GL047541. 
Eaton, D., A. Frederiksen, and S.-K. Miong (2004), Shear-wave splitting observations in the lower Great Lakes region: Evidence for regional anisotropic domains and keel-modified asthenospheric flow, Geophys. Res. Lett., 31(7), 4, doi:10.1029/2004GL019438.

Faccenda, M., and F. Capitanio (2012), Development of mantle seismic anisotropy during subduction-induced 3-D flow, Geophys. Res. Lett., 39(11), doi:10.1029/2012GL051988.

Fillerup, M. A., J. H. Knapp, C. C. Knapp, and V. Raileanu (2010), Mantle earthquakes in the absence of subduction? Continental delamination in the Romanian Carpathians, Lithosphere, 2(5), 333-340, doi:10.1130/L102.1.

Fodor, L., L. Csontos, G. Bada, I. Györfi, and L. Benkovics (1999), Tertiary tectonic evolution of the Pannonian Basin system and neighbouring orogens: a new synthesis of palaeostress data, Geol. Soc. Lond. Spec. Pub., 156(1), 295-334, doi:10.1144/GSL.SP.1999.156.01.15.

Geissler, W. H., F. Sodoudi, and R. Kind (2010), Thickness of the central and eastern European lithosphere as seen by S receiver functions, Geophys. J. Int., 181(2), 604-634, doi: 10.1111/j.1365-246X.2010.04548.x.

Gilligan, A., I. D. Bastow, E. Watson, F. A. Darbyshire, V. Levin, W. Menke, V. Lane, D. Hawthorn, A. Boyce, M. V. Liddell, et al. (2016), Lithospheric deformation in the Canadian Appalachians: evidence from shear wave splitting, Geophys. J. Int., doi: 10.1093/gji/ggw207.

Gîrbacea, R., and W. Frisch (1998), Slab in the wrong place: Lower lithospheric mantle delamination in the last stage of the Eastern Carpathian subduction retreat, Geology, 26(7), 611-614, doi:10.1130/0091-7613(1998)026<0611:SITWPL>2.3.CO;2.

Göğüs, O. H., R. N. Pysklywec, and C. Faccenna (2016), Postcollisional lithospheric evolution of the Southeast Carpathians: Comparison of geodynamical models and observations, Tectonics, 35(5), 1205-1224, doi:10.1002/2015TC004096.

Gripp, A., and R. Gordon (2002), Young tracks of hotspots and current plate velocities, Geophys. J. Int., 150(2), 321-361, doi:10.1046/j.1365-246X.2002.01627.x.

Handy, M. R., K. Ustaszewski, and E. Kissling (2015), Reconstructing the Alps-Carpathians-Dinarides as a key to understanding switches in subduction polarity, slab gaps and surface motion, Int. J. Earth Sci., 104(1), 1-26, doi:10.1007/s00531-014-1060-3. 
Horváth, F. (1993), Towards a mechanical model for the formation of the Pannonian basin, Tectonophysics, 226(1-4), 333-357, doi:10.1016/0040-1951(93)90126-5.

Horváth, F., G. Bada, P. Szafián, G. Tari, A. Ádám, and S. Cloetingh (2006), Formation and deformation of the Pannonian Basin: constraints from observational data, Geol. Soc. Lond. Spec. Pub., 32(1), 191-206, doi:10.1144/GSL.MEM.2006.032.01.11.

Huismans, R. S., Y. Y. Podladchikov, and S. Cloetingh (2001), Transition from passive to active rifting: Relative importance of asthenospheric doming and passive extension of the lithosphere, J. Geophys. Res., 106(B6), 11,271-11,291, doi:10.1029/2000JB900424.

Iancu, V., T. Berza, A. Seghedi, I. Gheuca, and H.-P. Hann (2005), Alpine polyphase tectonometamorphic evolution of the South Carpathians: a new overview, Tectonophysics, 410(1-4), 337-365, doi:10.1016/j.tecto.2004.12.038.

Ismail-Zadeh, A., L. Matenco, M. Radulian, S. Cloetingh, and G. Panza (2012), Geodynamics and intermediate-depth seismicity in Vrancea (the south-eastern Carpathians): current stateof-the art, Tectonophysics, 530, 50-79, doi:10.1016/j.tecto.2012.01.016.

Ivan, M., L. Tóth, and M. Kiszely (2002), SKS Splitting observed at the Hungarian station PSZ-Geofon Network, J. Balkan Geophys. Soc., 5(3), 71-76.

Ivan, M., M. Popa, and D. Ghica (2008), SKS splitting observed at Romanian broad-band seismic network, Tectonophysics, 462(1-4), 89-98, doi:10.1016/j.tecto.2007.12.015.

Karato, S., and H. Jung (1998), Water, partial melting and the origin of seismic low velocity and high attenuation zone in the upper mantle, Earth Planet. Sci. Lett., 157(3), 193-207, doi:10.1016/S0012-821X(98)00034-X.

Karato, S.-i., H. Jung, I. Katayama, and P. Skemer (2008), Geodynamic significance of seismic anisotropy of the upper mantle: new insights from laboratory studies, Annu. Rev. Earth Planet. Sci., 36, 59-95, doi:10.1146/annurev.earth.36.031207.124120.

Katayama, I., H. Jung, and S.-i. Karato (2004), New type of olivine fabric from deformation experiments at modest water content and low stress, Geology, 32(12), 1045-1048, doi: 10.1130/G20805.1.

Kendall, J.-M. (1994), Teleseismic arrivals at a mid-ocean ridge: effects of melt and anisotropy, Geophys. Res. Lett., 21, 301-304, doi:10.1029/93GL02791. 
King, S., and D. Anderson (1998), Edge-driven convection, Earth Planet. Sci. Lett., 160, 289296, doi:10.1016/S0012-821X(98)00089-2.

Knapp, J. H., C. C. Knapp, V. Raileanu, L. Matenco, V. Mocanu, and C. Dinu (2005), Crustal constraints on the origin of mantle seismicity in the Vrancea Zone, Romania: The case for active continental lithospheric delamination, Tectonophysics, 410(1), 311-323, doi: 10.1016/j.tecto.2005.02.020.

Kovács, I., G. Falus, G. Stuart, K. Hidas, C. Szabó, M. Flower, E. Hegedűs, K. Posgay, and L. Zilahi-Sebess (2012), Seismic anisotropy and deformation patterns in upper mantle xenoliths from the central Carpathian-Pannonian region: Asthenospheric flow as a driving force for Cenozoic extension and extrusion?, Tectonophysics, 514, 168-179, doi: 10.1016/j.tecto.2011.10.022.

Kreemer, C., G. Blewitt, and E. C. Klein (2014), A geodetic plate motion and Global Strain Rate Model, Geochem., Geophys., Geosyst., 15(10), 3849-3889, doi:10.1002/2014GC005407.

Kummerow, J., R. Kind, T. W. Group, et al. (2006), Shear wave splitting in the Eastern Alps observed at the TRANSALP network, Tectonophysics, 414(1-4), 117-125, doi: 10.1016/j.tecto.2005.10.023.

Kuo, B.-Y., S.-C. Lin, and Y.-W. Lin (2018), SKS splitting and the scale of vertical coherence of the Taiwan mountain belt, J. Geophys. Res., 123(2), 1366-1380, doi:10.1002/2017JB014803.

Liddell, M. V., I. Bastow, F. Darbyshire, A. Gilligan, and S. Pugh (2017), The formation of Laurentia: Evidence from shear wave splitting, Earth Planet. Sci. Lett., 479, 170-178, doi:10.1016/j.epsl.2017.09.030.

Linzer, H.-G. (1996), Kinematics of retreating subduction along the Carpathian arc, Romania, Geology, 24(2), 167-170, doi:10.1130/0091-7613(1996)024<0167:KORSAT>2.3.CO;2.

Little, T. A., M. K. Savage, and B. Tikoff (2002), Relationship between crustal finite strain and seismic anisotropy in the mantle, Pacific-Australia plate boundary zone, South Island, New Zealand, Geophys. J. Int., 151(1), 106-116, doi:10.1046/j.1365-246X.2002.01730.x.

Liu, K. H., and S. S. Gao (2013), Making reliable shear-wave splitting measurements, Bull. Seis. Soc. Am., 103(5), 2680-2693, doi:10.1785/0120120355. 
Long, M., and P. Silver (2009), Shear Wave Splitting and Mantle Anisotropy: Measurements, Interpretations, and New Directions, Surveys in Geophysics, 30(4), 407-461, doi: $10.1007 / \mathrm{s} 10712-009-9075-1$.

Long, M. D., and T. W. Becker (2010), Mantle dynamics and seismic anisotropy, Earth Planet. Sci. Lett., 297(3), 341-354, doi:10.1016/j.epsl.2010.06.036.

Long, M. D., and P. G. Silver (2008), The subduction zone flow field from seismic anisotropy: A global view, science, 319(5861), 315-318, doi:10.1126/science.1150809.

Lorinczi, P., and G. Houseman (2009), Lithospheric gravitational instability beneath the Southeast Carpathians, Tectonophysics, 474 (1-2), 322-336, doi:10.1016/j.tecto.2008.05.024.

Lucente, F. P., L. Margheriti, C. Piromallo, and G. Barruol (2006), Seismic anisotropy reveals the long route of the slab through the western-central Mediterranean mantle, Earth Planet. Sci. Lett., 241(3-4), 517-529, doi:10.1016/j.epsl.2005.10.041.

Mainprice, D., and A. Nicolas (1989), Development of shape and lattice preferred orientations: application to the seismic anisotropy of the lower crust, J. Struct. Geol., 11, 175-189, doi: 10.1016/0191-8141(89)90042-4.

Martin, M., F. Wenzel, and C. W. Group (2006), High-resolution teleseismic body wave tomography beneath SE-Romania-II. Imaging of a slab detachment scenario, Geophys. J. Int., 164(3), 579-595, doi:10.1111/j.1365-246X.2006.02884.x.

Martin-Short, R., R. M. Allen, I. D. Bastow, E. Totten, and M. A. Richards (2015), Mantle flow geometry from ridge to trench beneath the Gorda-Juan de Fuca plate system, Nature Geosci., 8(12), 965-968, doi:10.1038/ngeo2569.

Maţenco, L. (2017), Tectonics and exhumation of Romanian Carpathians: inferences from kinematic and thermochronological studies, in Landform Dyn. and Ev. in Romania, pp. 1556, Springer.

Maţenco, L., and G. Bertotti (2000), Tertiary tectonic evolution of the external East Carpathians (Romania), Tectonophysics, 316(3-4), 255-286, doi:10.1016/S0040-1951(99)00261-9.

Matenco, L., and D. Radivojević (2012), On the formation and evolution of the Pannonian Basin: Constraints derived from the structure of the junction area between the Carpathians and Dinarides, Tectonics, 31(6), doi:10.1029/2012TC003206. 
McNamara, D., T. Owens, P. Silver, and F. Wu (1994), Shear wave anisotropy beneath the Tibetan plateau, J. Geophys. Res., 99, 13,655-13,665, doi:10.1029/93JB03406.

Meissner, R., W. D. Mooney, and I. Artemieva (2002), Seismic anisotropy and mantle creep in young orogens, Geophys. J. Int., 149 (1), 1-14, doi:10.1046/j.1365-246X.2002.01628.x.

Miller, M., and T. Becker (2012), Mantle flow deflected by interactions between subducted slabs and cratonic keels, Nat. Geosci., 5(726-731), doi:10.1038/NGEO1553.

Moore, M., P. England, and B. Parsons (2002), Relation between surface velocity field and shear wave splitting in the South Island of New Zealand, J. Geophys. Res., 107(B9), doi: 10.1029/2000JB000093.

Nicolas, A., and N. Christensen (1987), Formation of anisotropy in upper mantle peridotites-A review, Composition, structure and dynamics of the lithosphere-asthenosphere system, 16, $111-123$.

Petrescu, L., G. Stuart, D. Tataru, and B. Grecu (2019), Crustal structure of the Carpathian Orogen in Romania from receiver functions and ambient noise tomography: how craton collision, subduction and detachment affect the crust, Geophys. J. Int., 218(1), 163-178, doi:10.1093/gji/ggz140.

Pharaoh, T., J. Winchester, J. Verniers, A. Lassen, and A. Seghedi (2006), The western accretionary margin of the East European Craton: an overview, Memoirs- Geol. Soc. London, 32, 291, doi:10.1144/GSL.MEM.2006.032.01.17.

Plenefisch, T., K. Klinge, and R. Kind (2001), Upper mantle anisotropy at the transition zone of the Saxothuringicum and Moldanubicum in southeast Germany revealed by shear wave splitting, Geophys. J. Int., 144(2), 309-319, doi:10.1046/j.0956-540X.2000.01316.x.

Plomerová, J., and V. Babuska (2010), Long memory of mantle lithosphere fabric European LAB constrained from seismic anisotropy, Lithos, 120(1), 131-143, doi: 10.1016/j.lithos.2010.01.008.

Plomerová, J., L. Vecsey, and V. Babuška (2012), Mapping seismic anisotropy of the lithospheric mantle beneath the northern and eastern Bohemian Massif (central Europe), Tectonophysics, 564, 38-53, doi:10.1016/j.tecto.2011.08.011. 
Popa, M., M. Radulian, C. Panaiotu, and F. Borleanu (2008), Lithosphere-asthenosphere interaction at the Southeastern Carpathian Arc bend: Implications for anisotropy, Tectonophysics, 462(1-4), 83-88, doi:10.1016/j.tecto.2008.03.017.

Popa, M., M. Radulian, D. Ghica, C. Neagoe, and E. Nastase (2015), Romanian Seismic Network since 1980 to the present, in Nonlinear Mathematical Physics and Natural Hazards, pp. 117-131, Springer.

Qorbani, E., I. Bianchi, and G. Bokelmann (2015), Slab detachment under the Eastern Alps seen by seismic anisotropy, Earth Planet. Sci. Lett., 409, 96-108, doi:10.1016/j.epsl.2014.10.049.

Qorbani, E., G. Bokelmann, I. Kovács, F. Horváth, and G. Falus (2016), Deformation in the asthenospheric mantle beneath the Carpathian-Pannonian Region, J. Geophys. Res., 121(9), 6644-6657, doi:10.1002/2015JB012604.

Ren, Y., G. Stuart, G. Houseman, B. Dando, C. Ionescu, E. Hegedüs, S. Radovanović, Y. Shen, S. C. P. W. Group, et al. (2012), Upper mantle structures beneath the Carpathian-Pannonian region: Implications for the geodynamics of continental collision, Earth Planet. Sci. Lett., 349 , 139-152, doi:10.1016/j.epsl.2012.06.037.

Restivo, A., and G. Helffrich (1999), Teleseismic shear wave splitting measurements in noisy environments, Geophys. J. Int., 137, 821-830, doi:10.1046/j.1365-246x.1999.00845.x.

Restivo, A., and G. Helffrich (2006), Core-mantle boundary structure investigated using SKS and SKKS polarization anomalies, Geophys. J. Int., 165(1), 288-302, doi:10.1111/j.1365246X.2006.02901.x.

Ribe, N. M. (1992), On the relation between seismic anisotropy and finite strain, J. Geophys. Res., 97(B6), 8737-8747, doi:10.1029/92JB00551.

Russo, R., and P. Silver (1994), Trench-parallel flow beneath the Nazca plate from seismic anisotropy, Science, 263(5150), 1105-1111, doi:10.1126/science.263.5150.1105.

Salimbeni, S., S. Pondrelli, and L. Margheriti (2013), Hints on the deformation penetration induced by subductions and collision processes: Seismic anisotropy beneath the Adria region (Central Mediterranean), J. Geophys. Res., 118(11), 5814-5826, doi:10.1002/2013JB010253.

Salimbeni, S., M. G. Malusà, L. Zhao, S. Guillot, S. Pondrelli, L. Margheriti, A. Paul, S. Solarino, C. Aubert, T. Dumont, et al. (2018), Active and fossil mantle flows in the western 
Alpine region unravelled by seismic anisotropy analysis and high-resolution $\mathrm{P}$ wave tomography, Tectonophysics, 731, 35-47, doi:10.1016/j.tecto.2018.03.002.

Savage, M. (1999), Seismic anisotropy and mantle deformation: What have we learned from shear wave splitting?, Rev. Geophys., 37, 65-106, doi:10.1029/98RG02075.

Schmid, S. M., D. Bernoulli, B. Fügenschuh, L. Matenco, S. Schefer, R. Schuster, M. Tischler, and K. Ustaszewski (2008), The Alpine-Carpathian-Dinaridic orogenic system: correlation and evolution of tectonic units, Swiss J. Geosci., 101(1), 139-183, doi:10.1007/s00015-0081247-3.

Seghedi, I., L. Maţenco, H. Downes, P. R. Mason, A. Szakács, and Z. Pécskay (2011), Tectonic significance of changes in post-subduction Pliocene-Quaternary magmatism in the south east part of the Carpathian-Pannonian Region, Tectonophysics, 502(1-2), 146-157, doi:10.1016/j.tecto.2009.12.003.

Şengül Uluocak, E., R. Pysklywec, O. Göğüş, and E. Ulugergerli (2019), Multi-Dimensional Geodynamic Modeling in the Southeast Carpathians: Upper Mantle Flow Induced Surface Topography Anomalies, Geochem. Geophys. Geosyst., doi:10.1029/2019GC008277.

Silver, P., and G. Chan (1991), Shear wave splitting and subcontinental mantle deformation, J. Geophys. Res., 96(B10), 16,429-16,454, doi:10.1029/91JB00899.

Silver, P., and W. Chan (1988), Implications for continental structure and evolution from seismic anisotropy, Nature, 335 (6185), 34-39.

Silver, P., and M. Savage (1994), The interpretation of shear wave splitting parameters in the presence of two anisotropic layers, Geophys. J. Int., 119, 949-963, doi:10.1111/j.1365246X.1994.tb04027.x.

Silver, P. G. (1996), Seismic anisotropy beneath the continents: Probing the depths of geology, Annu. Rev. Earth Planet. Sci., 24(1), 385-432.

Skemer, P., J. M. Warren, and G. Hirth (2012), The influence of deformation history on the interpretation of seismic anisotropy, Geochem. Geophys. Geosyst., 13(3), doi: 10.1029/2011GC003988. 
Song, W., Y. Yu, C. Shen, F. Lu, and F. Kong (2019), Asthenospheric flow beneath the Carpathian-Pannonian region: Constraints from shear wave splitting analysis, Earth Planet. Sci. Lett., 520, 231-240, doi:10.1016/j.epsl.2019.05.045.

Sperner, B., F. Lorenz, K. Bonjer, S. Hettel, B. Müller, and F. Wenzel (2001), Slab break-offabrupt cut or gradual detachment? New insights from the Vrancea Region (SE Carpathians, Romania), Terra Nova, 13(3), 172-179, doi:10.1046/j.1365-3121.2001.00335.x.

Stanciu, A., R. Russo, V. Mocanu, and L. Munteanu (2013), Shear-wave splitting within the Southeastern Carpathian Arc, Transylvanian Basin, Romania, J. Geodyn., 70, 61-69, doi: 10.1016/j.jog.2013.05.003.

Tari, G., F. Horváth, and J. Rumpler (1992), Styles of extension in the Pannonian Basin, Tectonophysics, 208(1-3), 203-219, doi:10.1016/0040-1951(92)90345-7.

Teanby, N., J.-M. Kendall, and M. Van der Baan (2004), Automation of shear-wave splitting measurements using cluster analysis, Bull. Seis. Soc. Am., 94(2), 453-463, doi: $10.1785 / 0120030123$.

Ustaszewski, K., S. M. Schmid, B. FüGENSCHUH, M. Tischler, E. Kissling, and W. Spakman (2008), A map-view restoration of the Alpine-Carpathian-Dinaridic system for the Early Miocene, Swiss J. Geosci., 101 (1), 273-294, doi:10.1007/s00015-008-1288-7.

Vauchez, A., and A. Nicolas (1991), Mountain building: strike-parallel motion and mantle anisotropy, Tectonophysics, $185(3), 183-201$.

Vecsey, L., J. Plomerová, and V. Babuška (2008), Shear-wave splitting measurements-Problems and solutions, Tectonophysics, 462(1-4), 178-196, doi:10.1016/j.tecto.2008.01.021.

Venereau, C., R. Martin-Short, I. Bastow, R. Allen, and R. Kounoudis (2019), The Role of Variable Slab Dip in Driving Mantle Flow at the Eastern Edge of the Alaskan Subduction Margin: Insights From Shear-Wave Splitting, Geochem. Geophys. Geosyst., 20, doi: 10.1029/2018GC008170.

Vinnik, L., L. Makeyeva, A. Milev, and A. Usenko (1992), Global patterns of azimuthal anisotropy and deformation in the continental mantle, Geophys. J. Int., 111, 433-447, doi: 10.1111/j.1365-246X.1992.tb02102.x. 
Vinnik, L., V. Krishna, R. Kind, P. Bormann, and K. Stammler (1994), Shear wave splitting in the records of the German Regional Seismic Network, Geophys. Res. Lett., 21(6), 457-460, doi:10.1029/94GL00396.

Walsh, E., R. Arnold, and M. Savage (2013), Silver and Chan revisited, J. Geophys. Res., 118(10), 5500-5515, doi:10.1002/jgrb.50386.

Wang, C.-Y., L. M. Flesch, P. G. Silver, L.-J. Chang, and W. W. Chan (2008), Evidence for mechanically coupled lithosphere in central Asia and resulting implications, Geology, 36(5), 363-366, doi:0.1130/G24450A.1.

Wessel, P., and W. H. Smith (1998), New, improved version of Generic Mapping Tools released, Eos, Transactions American Geophysical Union, 79(47), 579-579.

Wiejacz, P. (2001), Shear wave splitting across Tornquist-Teisseyre zone in Poland, J. Balkan Geophys. Soc., 4(4), 91-100.

Wortel, M., and W. Spakman (2000), Subduction and slab detachment in the MediterraneanCarpathian region, Science, 290(5498), 1910-1917, doi:10.1126/science.290.5498.1910.

Worthington, J. R., B. R. Hacker, and G. Zandt (2013), Distinguishing eclogite from peridotite: EBSD-based calculations of seismic velocities, Geophys. J. Int., 193(1), 489-505, doi:10.1093/gji/ggt004.

Wylegalla, K., G. Bock, J. Gossler, W. Hanka, T. W. Group, et al. (1999), Anisotropy across the Sorgenfrei-Tornquist Zone from shear wave splitting, Tectonophysics, 314(1-3), 335-350, doi:10.1016/S0040-1951(99)00252-8.

Xue, M., and R. M. Allen (2005), Asthenospheric channeling of the Icelandic upwelling: Evidence from seismic anisotropy, Earth Planet. Sci. Lett., 235(1-2), 167-182, doi: 10.1016/j.epsl.2005.03.017.

Zandt, G., and E. Humphreys (2008), Toroidal mantle flow through the western US slab window, Geology, 36(4), 295-298, doi:10.1130/G24611A.1.

Zeyen, H., J. Dérerová, and M. Bielik (2002), Determination of the continental lithospheric thermal structure in the Western Carpathians: integrated modelling of surface heat flow, gravity anomalies and topography, Phys. Earth Planet. Int., 134(1-2), 89-104, doi:10.1016/S00319201(02)00155-3. 
766

767

768

769

770

771

Zhang, S., and S.-I. Karato (1995), Lattice preferred orientation of olivine aggregates deformed in simple shear, Nature, 375, 774-777, doi:10.1038/375774a0.

Zhu, H., E. Bozdă̆, and J. Tromp (2015), Seismic structure of the European upper mantle based on adjoint tomography, Geophys. J. Int., 201(1), 18-52, doi:10.1093/gji/ggu492.

Zielhuis, A., and G. Nolet (1994), Deep seismic expression of an ancient plate boundary in Europe, Science, 265(5168), 79-81, doi:10.1126/science.265.5168.79. 


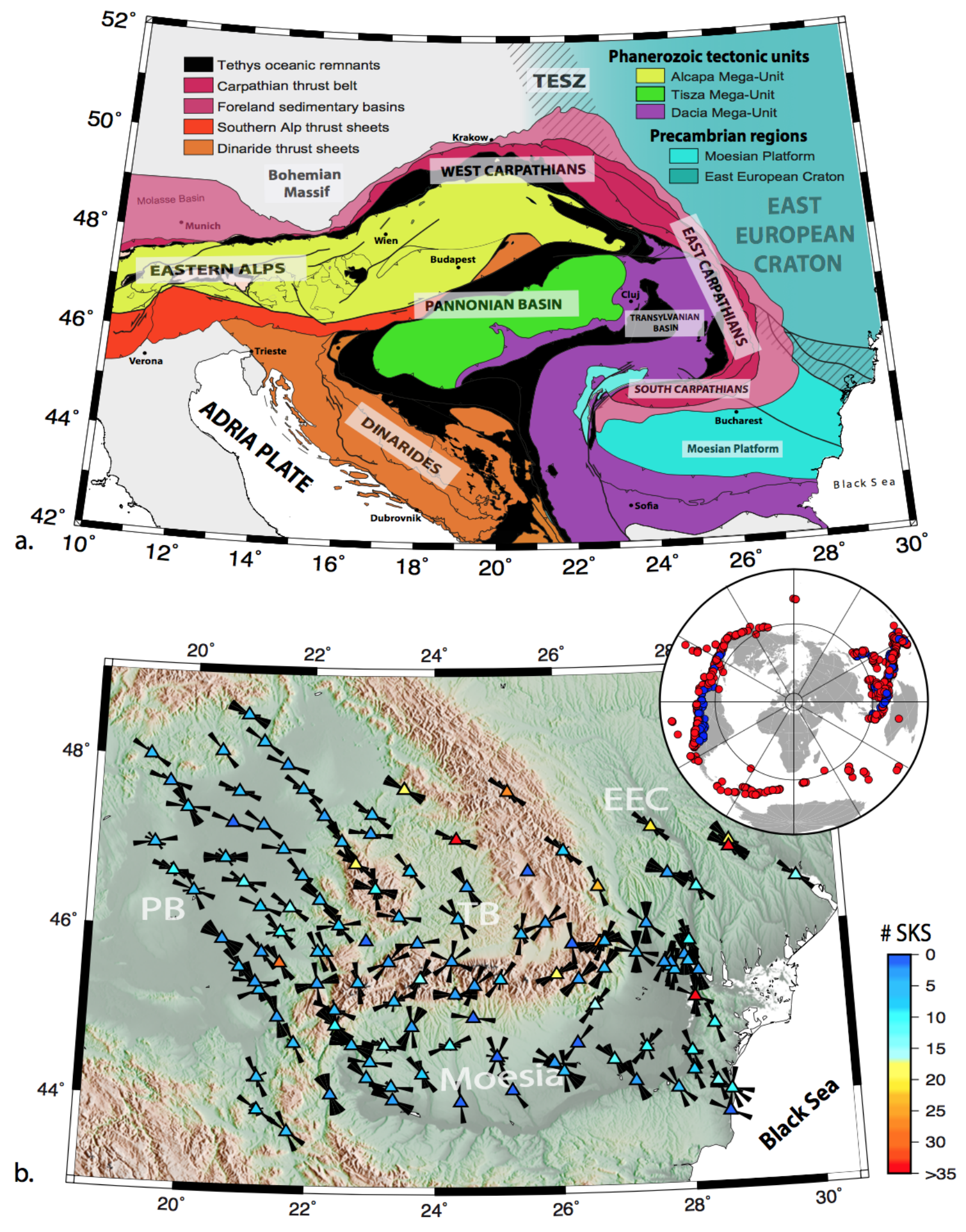

Figure 1: a. Geological map of Central and Eastern Europe showing the major tectonic provinces (after Ustaszewski et al., 2008) and geographical regions. b. Topographic map of Eastern Europe with all the SKS fast axis orientation measurements shown as rose histograms and the total number of measurements shown as coloured triangles at each station location. Inset: Back-azimuthal distribution of teleseismic earthquakes recorded at SCP and NIEP seismic stations, for which reliable SKS measurements were obtained. Red and blue circles indicate hypocentral depths deeper, or shallower than $100 \mathrm{~km}$, respectively. 


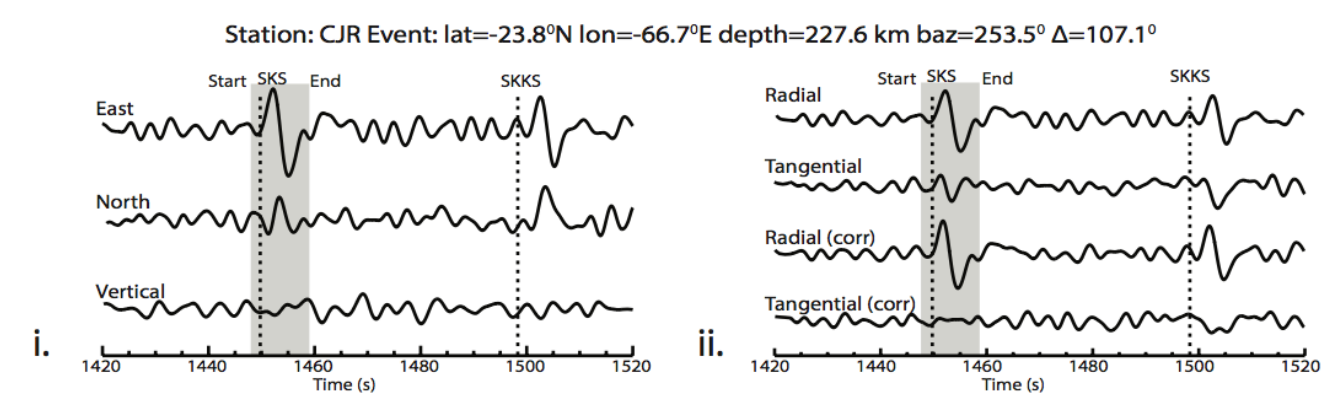

a.
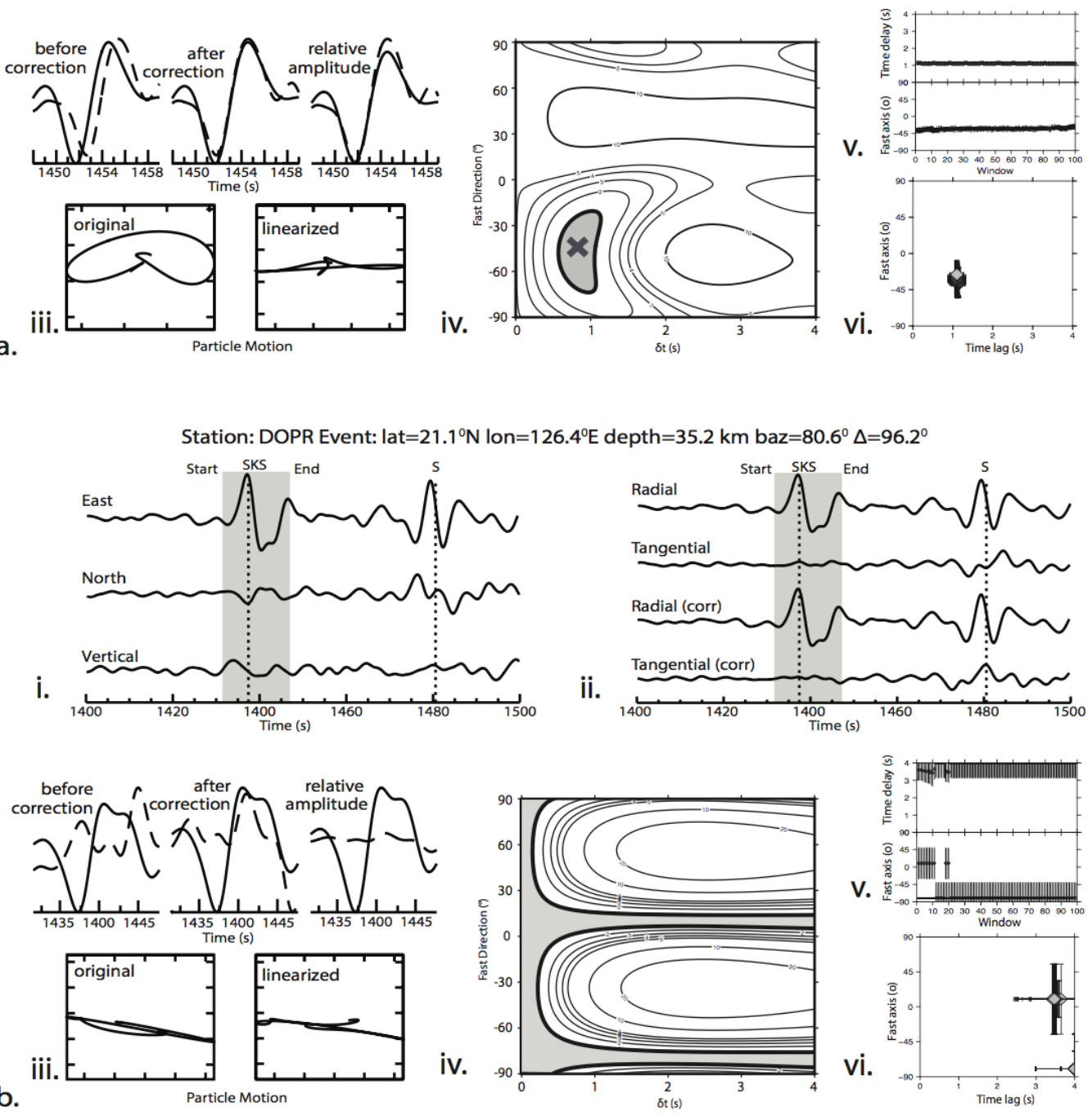

Figure 2: Examples of shear wave splitting analysis. (a) A high quality split (i) Original three-component seismogram showing the expected SKS arrival based on the iaspei reference Earth model and the selected window for analysis (marked with START and END). (ii) The rotated radial and tangential seismograms before (top) and after (bottom) analysis; the corrected tangential component shows minimal SKS energy. (iii) Top images are windowed seismograms showing the match between the fast (dashed line) and slow (solid line) waveforms, prior to correction with normalised amplitudes (left) and after correction (centre - amplitude-normalised and right - relative amplitude). Bottom images show the original elliptical particle motion and the linearized particle motion after correction in the R-T horizontal planes, respectively. (iv) Graphic output of the grid search and cluster analysis of splitting parameters, with contours indicating multiples of one-sigma error. (v) Example of SKS splitting parameters obtained from 100 different time windows around the SKS phase, showing the stability of the result. (vi) Example of $\phi$ and $d t$ result obtained from the automated cluster analysis (Teanby et al., 2004). (b) A high-quality null measurement, where no energy was identified on the tangential component (ii) and the particle motion is linear before analysis (iii). 

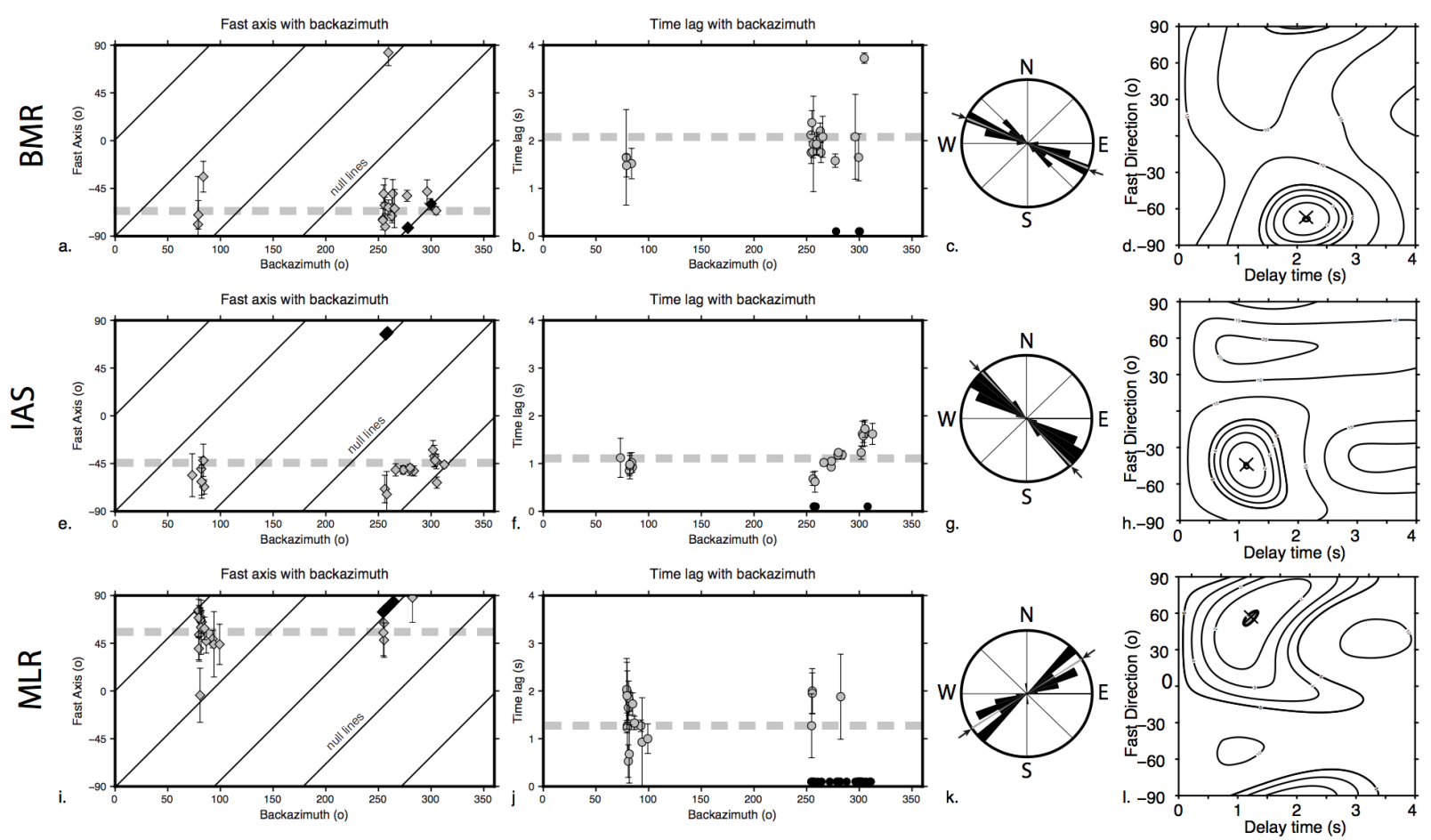

Figure 3: Examples of single station SKS splitting results plotted as a function of earthquake back-azimuth. Station locations are labelled in Figure 1. a,e,i. SKS fast axis polarisation directions as a function of backazimuth. Black diamonds are null results, with fast axis considered equal to the back-azimuth. Dashed grey line is the $\phi$ value obtained from misfit surface stacking (Restivo and Helffrich, 1999). Slanted lines are the expected hypothetical null measurement loci if the SKS direction is parallel or perpendicular to any given $\phi$ direction, under the assumption of simple anisotropy. b,f,j. SKS splitting delay times as a function of back-azimuth. Black circles are null measurements. c,g,k. Rose diagrams of SKS fast axis directions and the misfit stacking value (grey line and black arrows). d,h,i. Stacked error surfaces for all non-null solutions, showing the best $\phi$ - $d t$ solution pair (black X). 

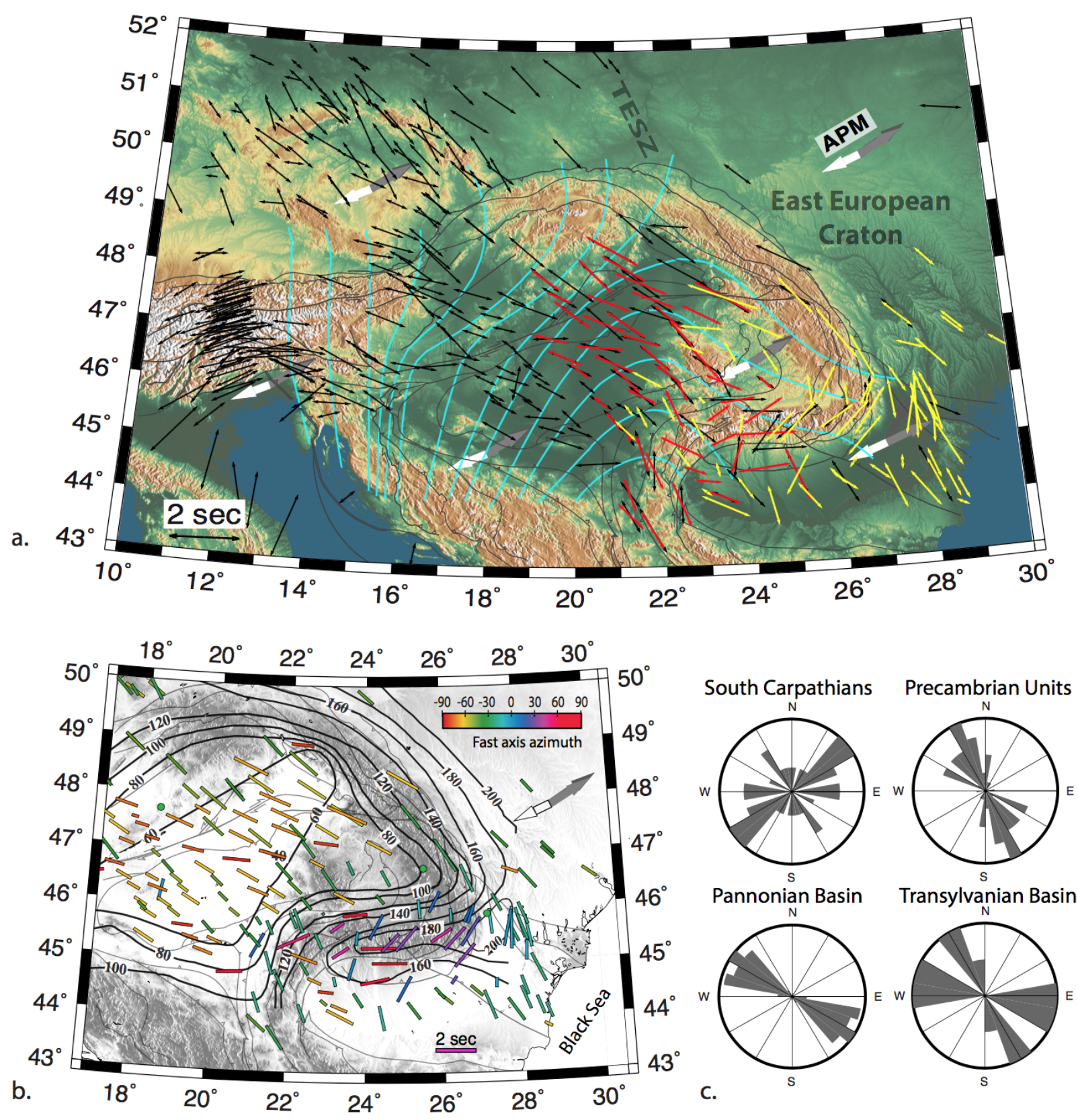

c.

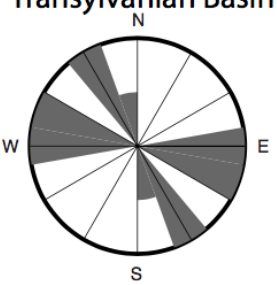

Figure 4: a. Topographic map of central and eastern Europe showing SKS results past and present. Length of SKS fast axis is proportional to the delay time. Red (SCP network) and yellow (RO network) vectors are our SKS measurements (found in Supplementary Material). Black vectors are SKS splitting measurements estimated in past papers (Vinnik et al., 1994; Dricker et al., 1999; Wylegalla et al., 1999; Plenefisch et al., 2001; Wiejacz, 2001; Kummerow et al., 2006; Ivan et al., 2008; Vecsey et al., 2008; Plomerová et al., 2012; Salimbeni et al., 2013; Qorbani et al., 2015, 2016; Song et al., 2019). The cyan lines are the trajectories of maximum horizontal stress orientations after Bada et al. (2007) and Dombrádi et al. (2010). The thick arrows represent plate motion directions in the no-net rotation frame for Eurasia (dark grey: Kreemer et al. (2014), grey: DeMets et al. (2010)) and the hot-spot reference frame (white, Gripp and Gordon, 2002) with magnitudes varying between $22 \mathrm{~mm} / \mathrm{yr}$ and $30 \mathrm{~mm} / \mathrm{yr}$. b. Topographic map of Eastern Europe showing our new SKS results coloured with respect to fast axis orientation and the lithosphere-asthenosphere boundary contours, modified after Kovács et al. (2012), compiled from Horváth (1993); Ádám and Wesztergom (2001); Zeyen et al. (2002); Bielik et al. (2010). c. Rose diagrams of SKS anisotropy orientations in selected geological regions. 

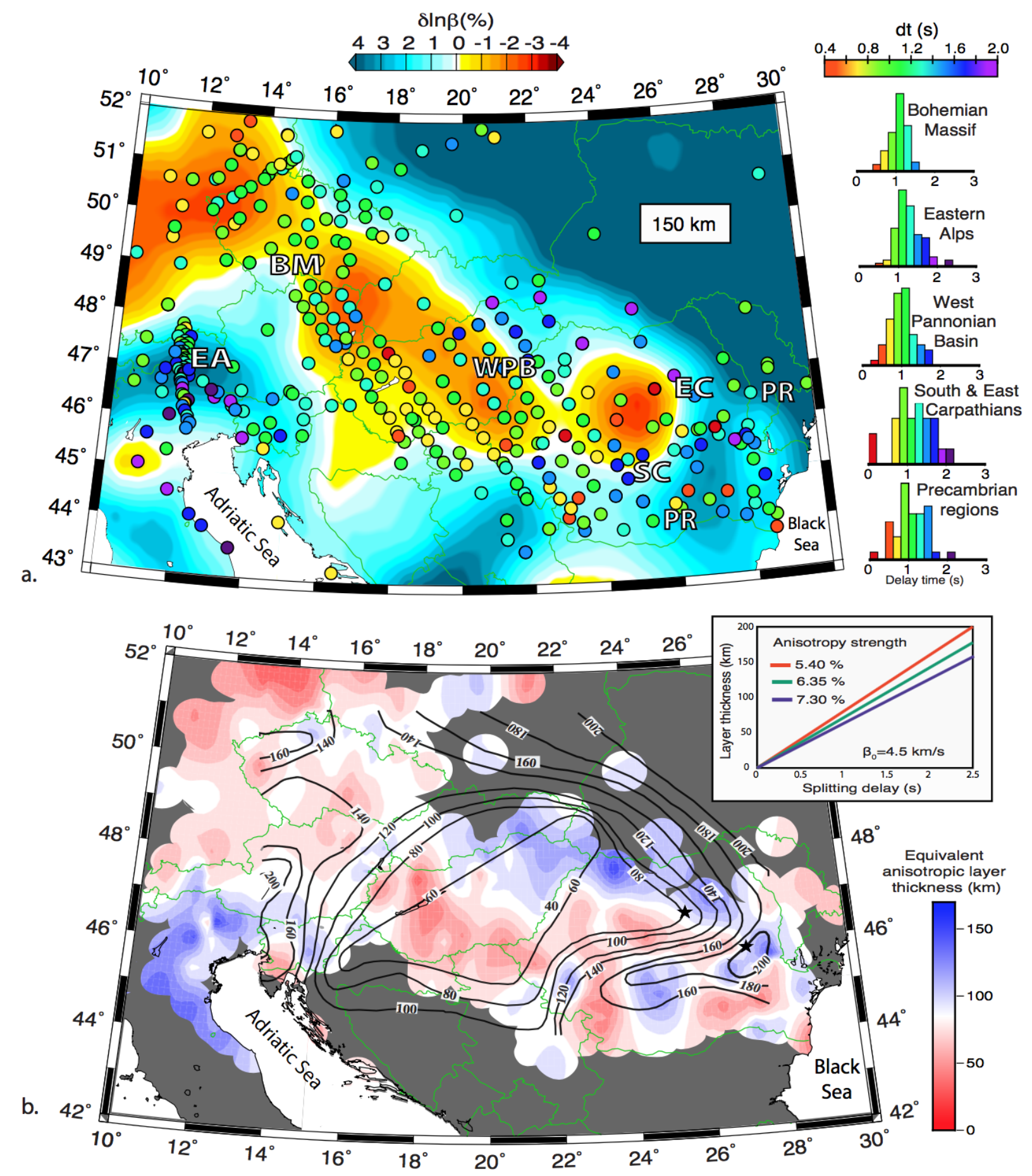

Figure 5: a. Map of Central and Eastern Europe showing SKS splitting delay times obtained in this study and those studies cited in Figure 4, overlain on S-wave seismic tomography at $150 \mathrm{~km}$ depth (Zhu et al., 2015). Right inset: normalised histograms of splitting delay time values obtained at stations located in selected regions. b. Thickness of the equivalent anisotropy layer, calculated based on stacked SKS splitting delay times (excluding null values) estimated at broadband seismic stations, average $\mathrm{k}=6.35 \%$ (Kovács et al., 2012), and shear wave velocity values from $Z$ hhu et al. (2015). Stars mark the location of stations where only null measurements were obtained. The layer map is smoothed using the gmt surface function (Wessel and Smith, 1998) with a tension factor of 0.5 and grid spacing of $50^{\prime}$, and masked at $50 \mathrm{~km}$ around seismic station locations, the approximate radius of the SKS Fresnel zone at 150-200 km depth. Contours indicate the depth to the lithosphereasthenosphere boundary (references in Figure 4). Left inset: Anisotropic layer thickness, L, variation as a function of the splitting delay time, $d t$ using the equation defined by Silver and Chan (1988), for a range of $k$ values from (Kovács et al., 2012) and using $\beta_{0}=4.5 \mathrm{~km} / \mathrm{s}$. 

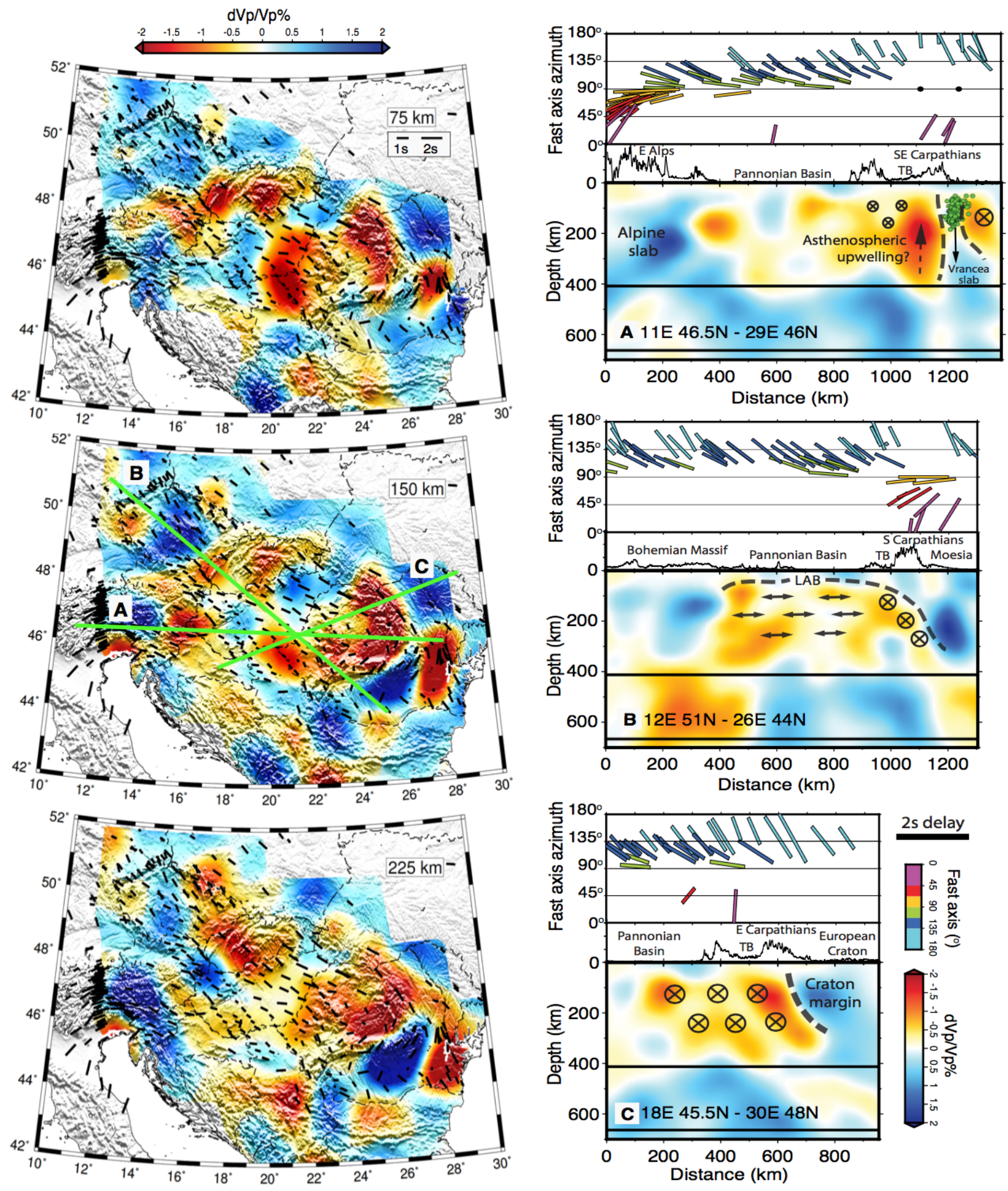

Figure 6: Left side: P-wave velocity tomography model (Ren et al., 2012) of Eastern and Central Europe at $75 \mathrm{~km}, 150 \mathrm{~km}$ and $225 \mathrm{~km}$ and SKS anisotropy polarisation vectors with length proportional to $d t$ (black bars). Right side: Cross-sections of P-wave velocity marked with green lines on the $150 \mathrm{~km}$ tomography depth slice. Green circles on tomography cross-sections are intermediate-depth earthquakes in the Vrancea Seismic Zone and black lines mark the $410 \mathrm{~km}$ and $660 \mathrm{~km}$ mantle discontinuities. Black double-sided arrows and crosses indicate the interpretation of mantle flow orientations that are parallel or perpendicular to the section plane, respectively. Above each section, SKS anisotropy axes measured at stations within $0.5^{\circ}$ distance from the section plane are plotted as bars coloured with respect to the fast axis orientation. Black circles represent null measurements. 